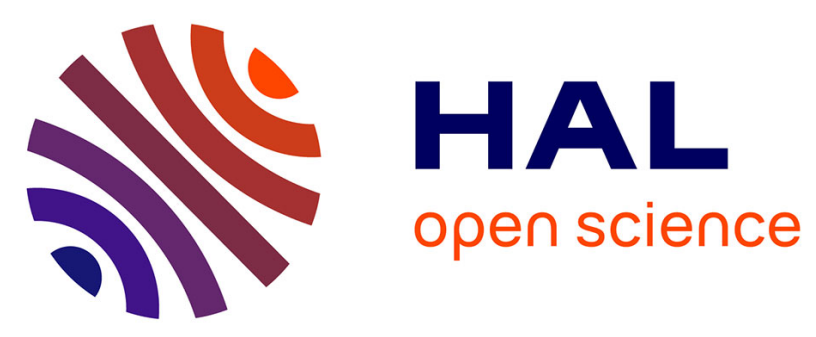

\title{
Pasta cooking time: influence on starch digestion and plasma glucose and insulin responses in healthy subjects
} Frédéric Bornet, D. Cloarec, J.L. Barry, Paul Colonna, S. Gouilloud, J. Delort-Laval, J.P. Galmiche

\section{- To cite this version:}

Frédéric Bornet, D. Cloarec, J.L. Barry, Paul Colonna, S. Gouilloud, et al.. Pasta cooking time: influence on starch digestion and plasma glucose and insulin responses in healthy subjects. The American Journal of Clinical Nutrition, 1990, 51 (3), pp.421-427. hal-02714179

HAL Id: hal-02714179

https://hal.inrae.fr/hal-02714179

Submitted on 1 Jun 2020

HAL is a multi-disciplinary open access archive for the deposit and dissemination of scientific research documents, whether they are published or not. The documents may come from teaching and research institutions in France or abroad, or from public or private research centers.

$$
\text { Copyright }
$$

L'archive ouverte pluridisciplinaire HAL, est destinée au dépôt et à la diffusion de documents scientifiques de niveau recherche, publiés ou non, émanant des établissements d'enseignement et de recherche français ou étrangers, des laboratoires publics ou privés. 


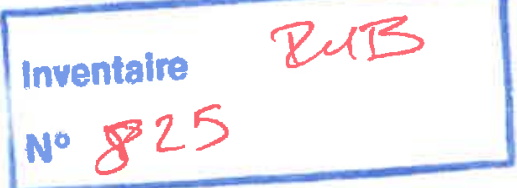

\title{
Pasta cooking time: influence on starch digestion and plasma glucose and insulin responses in healthy subjects ${ }^{1-3}$
}

\author{
Francis RJ Bornet, Denis Cloarec, Jean-Luc Barry, Paul Colonna, Sylvie Gouilloud,
Jean Delort Laval, and Jean-Paul Galmiche
}

\begin{abstract}
The influence of pasta cooking time on starch digestion and plasma glucose and insulin responses was studied in 12 healthy subjects. During 3 consecutive days, one of three pasta test meals $(50 \mathrm{~g}$ starch) cooked for $11,16.5$, and $22 \mathrm{~min}$ was served to each volunteer in a random order. Hydrogen and methane breath excretion was measured after pasta ingestion; plasma responses were compared with those of an equivalent oral glucose-tolerance test. No significant differences were found between cooking times and plasma indices, orocecal transit time, or incremental hydrogen excretion ( $\Delta$ peak hydrogen). With one exception, pasta meals that were completely absorbed were ingested by methane producers. Postprandial $\Delta$ peak hydrogen was significantly lower in methane than in nonmethane producers $(p<0.02)$. These results point to a lack of influence of cooking time on nutritional characteristics of pasta and suggest that starch malabsorption determined by breathhydrogen-test criteria may be underestimated in methane producers. Am J Clin Nutr 1990;51:421-7.
\end{abstract}

KEY WORDS Pasta, cooking time, breath-hydrogen test, breath-methane test, methane producer status, glycemic index, insulinemic index

\section{Introduction}

Starchy carbohydrates represent the major source of nutritive energy in humans. Recent investigations in man, with use of the breath-hydrogen test, indicated the existence of a malabsorption by the small bowel of most starchy foods including pasta $(1,2)$, which may not only modify energy food value but induce abdominal discomfort as well. Other studies showed that the digestion of durum-wheat pasta by diabetics and healthy subjects is characterized by reduced plasma glucose and insulin responses (3-5). Both sets of effects could be explained by a reduced susceptibility of pasta starch to digestion by $\alpha$-amylase. Digestibility of starch in foods by $\alpha$-amylase can be modified in vitro as well as in vivo by numerous factors including starch origin $(6,7)$, nonstarchy components such as fibers $(8,9)$ or glutinous protein $(1,10,11)$, and food processing (12-16). The aim of this study was to evaluate the effects of pasta cooking time on plasma glucose and insulin responses and on intestinal malabsorption of starch in healthy subjects by using the breath-hydrogen and -methane test methods.

\section{Methods \\ Subjects and experimental design}

Twelve young healthy volunteers [six men and six women, aged $22.6 \pm 2.5 \mathrm{y},(\bar{x} \pm \mathrm{SD})$ mean body mass index $20.8 \pm 2.6$ $\mathrm{kg} / \mathrm{m}^{2}$ ] with no history of gastrointestinal disease or diabetes gave their informed written consent to participate in a study approved by the Ethics Committee of the Hôpital Guillaume et René Laënnec.

The pasta test meals consisted of spaghetti, industrially produced (Panzani, Marseilles, France) from durum-wheat semolina and dried at a low temperature of $55^{\circ} \mathrm{C}$. The pasta $(100 \mathrm{~g}$ dry matter) was boiled in $2 \mathrm{~L} 0.7 \%$ salted Evian (BSN Co, Evian, France) water for either 11 (T1), 16.5 (T2), or $22 \mathrm{~min}$ (T3) on the basis of an established reference method (17). Immediately after cooking, the water was drained for $1 \mathrm{~min}$ through a colander with $1-\mathrm{mm}$ pores and the pasta meal was served. Each pasta test meal consisted of $50 \mathrm{~g}$ starch, $10 \mathrm{~g}$ protein, $1.6 \mathrm{glipids}, 275 \mathrm{kcal}$ ( $1150 \mathrm{~J}$ ), and a variable water content comprising 140, 180, and $220 \mathrm{~g}$ for the $\mathrm{T} 1, \mathrm{~T} 2$, and T3 test meals, respectively. To ensure uniformity of water content in the three test meals, an additional drink of water of 110,70 , and $30 \mathrm{~g}$ accompanied the $\mathrm{T} 1, \mathrm{~T} 2$, and $\mathrm{T} 3$ pasta meals, respectively. The chemical and physicochemical characteristics of pasta before and after cooking were reported by Colonna et al (18).

The order of the three pasta meals was randomly assigned to each volunteer during a 3-d consecutive test period by using a Latin-square experimental design; meals were eaten at $0900 \mathrm{~h}$ within $6 \mathrm{~min}$ after an overnight fast and immediately preceded by meticulous oral hygiene. Each evening meal preceding the morning test was standardized to contain a low level of indigestible material and consisted of fish $(100 \mathrm{~g})$, white rice (200

\footnotetext{
' From INRA, Laboratoire de Technologie Appliquée à la Nutrition; the Service d'Exploration Fonctionelle Digestive, Hôpital Guillaume et René Laënnec: INRA, Laboratoire de Biochimie et de Technologie des Glucides; and the GIS, Nutrition Glucidique de l'Homme Sain, Nantes, France.

${ }^{2}$ Supported by a grant from the Ministère de la Recherche et de l'Enseignement Supérieur (MRES), Paris.

${ }^{3}$ Address reprint requests to FRJ Bornet, INRA, Laboratoire de Technologie Appliquée à la Nutrition, BP 527 44026, Nantes Cedex 03, France.

Received September 14, 1988.

Accepted for pubiication April 12, 1989.
} 
g). white bread $(80 \mathrm{~g})$, a portion of Camembert cheese $(30 \mathrm{~g})$. and yogurt $(125 \mathrm{~g})$ : water ingestion was permitted ad libitum.

\section{Blood sampling and breath analysis}

Baseline testing was done during the week preceding the test meals, with volunteers subjected to an oral glucose-tolerance test and a lactulose test. The glucose tolerance test $(55.5 \mathrm{~g}$ monodehydrated D-glucose diluted in $250 \mathrm{~mL}$ water equivalent to $50 \mathrm{~g}$ starch glucose units) was performed at $0900 \mathrm{~h}$ after a 12-h fast. Blood samples were drawn $30 \mathrm{~min}$ before and every $15 \mathrm{~min}$ for $60 \mathrm{~min}$ after glucose ingestion followed by $30-\mathrm{min}$ sampling during the next $2 \mathrm{~h}$.

The lactulose test, consisting of $10 \mathrm{~g}$ lactulose syrup (Duphalac. Duphar Laboratories, Villeurbanne, France) in $100 \mathrm{~mL}$ water, was done at $0900 \mathrm{~h}$ after suitable oral hygiene (careful mouthwashing with a $1 \%$ chlorhexidine solution; Givalex, Norgan Laboratories, Paris) to reduce oropharyngeal microfloral activity $(19,20)$. Breath samples were collected at 15 -min intervals from $30 \mathrm{~min}$ before lactulose ingestion until $6 \mathrm{~h}$ afterwards. During the test, subjects were forbidden to eat, smoke, or exercise. Hydrogen-producer status was defined as the ability of a subject to produce an increase in breath hydrogen of $>20 \mathrm{ppm}$ above baseline values (nadir of the hydrogen concentration) at one or more breath collections after a standard lactulose ingestion $(21,22)$. Methane-producer status was defined as a mean breath-methane-sample concentration of $\geq 3 \mathrm{ppm}$ above that in ambient air.

Blood samples were drawn $30 \mathrm{~min}$ before and every $15 \mathrm{~min}$ during the hour after a pasta test meal, then every $30 \mathrm{~min}$ for the $2 \mathrm{~h}$ thereafter. Samples were immediately centrifuged at $9000 \times g$ for $10 \mathrm{~min}$ at $4{ }^{\circ} \mathrm{C}$ and frozen for later testing. Plasma glucose concentrations were assayed by using a glucose-oxidase method (Beckman Autoanalyzer II, Beckman, Fullerton, CA) with an intraassay reproducibility of $2 \%$. Plasma insulin was tested by radioimmunoassay (Anti-insulin antibody, Novo Industri, Copenhagen) by using a charcoal separation method with an intraassay reproducibility of $6 \%$.

The glycemic index was calculated for each pasta test meal as the ratio between the incremental areas under the 3-h glycemic response curve to a pasta meal and to the glucose tolerance test, expressed as a percent. The insulinemic index was similarly calculated from the respective insulin curves.

Breath samples were collected at 15 -min intervals from 30 min before to $9 \mathrm{~h}$ after ingestion of a test meal. Subjects remained seated and had access to water ad libitum after the first 3 -h test period. Alveolar air samples were obtained by having the subjects exhale through a mouthpiece into two bags connected by a three-way valve. When the first $500 \mathrm{~mL}$ of expiratory air filled one plastic bag, the end alveolar air was then collected in a second bag (1-L rubber anesthesia bag adapted with a one-way valve). The end alveolar air was then immediately transferred into $50-\mathrm{mL}$ plastic syringes fitted with threeway stopcocks, and was usually analyzed within $2 \mathrm{~h}$ of collection (23).

The hydrogen and methane concentrations in breath samples were determined simultaneously with a MICRO LYZER DP gas chromatograph (Quintron Instrument Company, Milwaukee, WI) by using a molecular sieve column (12' Hysep Q, $60 / 80$ mesh; Quintron Instrument $\mathrm{Co}$ ). Dry air was used as the carrier gas at a flow rate of $40 \mathrm{~mL} / \mathrm{min}$. The chromatograph was calibrated with a hydrogen and methane reference mixture in compressed air (Quingas 2, Quintron Instrument Co). The smallest detectable concentration of both gases was $2 \mathrm{ppm}$ with a linear accuracy response range of 2-150 ppm.

During the 9-h period after the pasta test meal, an increase in hydrogen concentration of $\geq 10 \mathrm{ppm}$ over baseline (nadir of the hydrogen concentration), measured upon two consecutive 15-min-interval breath samplings, was considered to represent significant starch malabsorption (24). Therefore, the orocecal transit time was defined as the time from the beginning of carbohydrate intake until the period just before the first detectable sustained increase in breath hydrogen $(22,25,26)$.

\section{Statistical analysis}

Analysis of variance was used to test the effect of subjects, cooking time, and order of pasta meals. Multiple comparisons between the test-meal data were made by using the method of Newman-Keuls (27). Analysis for significance between lactulose or glucose-tolerance-test data and that of the test meals was performed by using Student's $t$ test for paired data whereas comparison between methane-producer and nonmethane-producer data was made by using Student's $t$ test for unpaired data. Results are expressed as means $\pm \mathrm{SEM}$.

\section{Results}

\section{Responses in plasma}

The mean plasma glucose responses observed $180 \mathrm{~min}$ after the pasta meals and glucose tolerance test are shown in Figure 1, with the mean postprandial plasma glucose variations summarized in Table 1 . The mean glycemic $\Delta$ peak value occurred significantly faster $(p<0.05)$ after the T1 pasta meal $(31 \pm 2$ $\mathrm{min}$ ) than after the glucose tolerance test $(40 \pm 3 \mathrm{~min})$ but not significantly faster than after the other pasta test meals (T2 and T3). After the pasta meals the mean $\Delta$ plasma glucose responses above baseline fasting concentrations were only half as high as those after the glucose tolerance test $(p<0.001)$. The mean $\Delta$ peak plasma glucose under the baseline fasting value was also significantly greater $(p<0.001)$ after the glucose tolerance test than after the pasta meals. Although there were no significant differences in the plasma glucose responses between pasta meals in the 3-h postprandial test period, plasma glucose variations and areas under the plasma glucose curves or the glycemic indexes were generally significantly different when comparing values after the pasta test meals with those after the glucose tolerance test.

The mean plasma insulin profiles observed within $180 \mathrm{~min}$ of the pasta meals and the glucose tolerance test are illustrated in Figure 1 and summarized in Table 2. From 15 to $120 \mathrm{~min}$ after the start of the tests, insulin concentrations after the glucose tolerance test and after the pasta test meals differed significantly. However, insulin responses after the three pasta meals did not differ significantly.

\section{Breath excretion}

Although all subjects were hydrogen producers, only half were methane producers as well. The mean of maximal hydrogen increment ( $\Delta$ peak hydrogen) over basal breath hydrogen (nadir of the hydrogen concentration) after the lactulose test was $50.8 \pm 8.4 \mathrm{ppm}$ for the nonmethane producer group Lgroup $\mathrm{M}(-)]$ and $38 \pm 8.9 \mathrm{ppm}$ for the methane producer group 


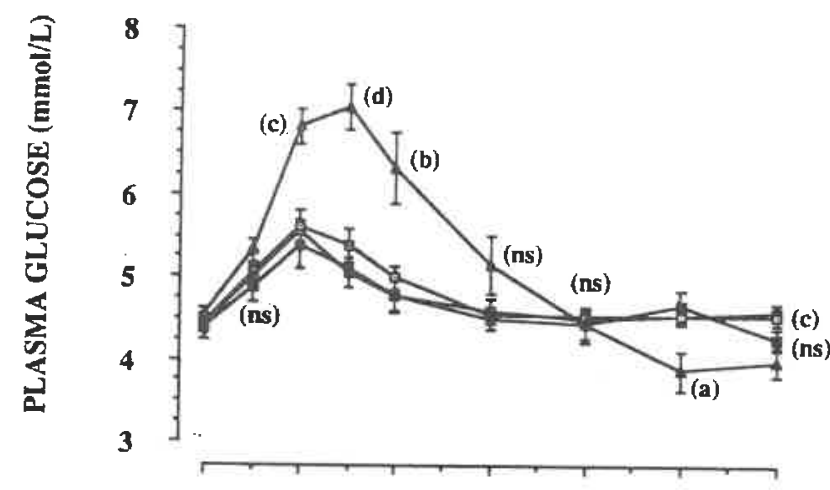

amylase susceptibility and in vivo starch bioavailability. Digestion of food starch by pancreatic amylase can be increased by a more disorganized state of the starch molecule. obtained by heating or shearing in excess water. This maximally disorganized state is a function of swelling temperature. which depends on the type of starch used (28).

In agreement with earlier studies in diabetics $(3,5)$ and in healthy subjects (4), our study confirmed that ingestion of white durum-wheat flour in the form of pasta by healthy subjects led to a significantly smaller increase in plasma glucose and insulin concentrations than after an equivalent glucose solution. Mean glycemic and insulinemic $\Delta$ peaks after pasta test meals occurred more rapidly than after the glucose tolerance test. The significant difference between the glucose tolerance test and the TI pasta meal in terms of plasma glucose peaking time may be ascribed to the relatively large time interval (15 min) between blood samplings. A shorter sampling time interval would probably have reduced the differences. Rather than consider pasta a slow carbohydrate, which supposes a delay in $\Delta$ peaking time and/or time to return to basal value, it may be better defined as a low-effect carbohydrate. Although plasma glucose concentrations decreased below fasting values after the second hour of the glucose tolerance test, this relative hypoglycemic phenomenon was not observed after the pasta meals. The more stable plasma glucose responses to pasta ingestion were a consequence of the lower insulin responses.

The lack of differences in plasmatic response and starch digestion between the three test meals are in accordance with in vitro results reported by Colonna et al (18), who showed by $x$ ray diffractometry or differential scanning calorimetry analysis that after cooking (T1) in boiled water, starch was yet completely gelatinized. Furthermore, in vitro starch pasta $\alpha$-amylolysis performed at $37^{\circ} \mathrm{C}$ (600 nkat of $\alpha$-amylase) shows that starch susceptibility to amylase increases after cooking: however, overcooking had only a slight effect. This lack of effect of the cooking time on the glycemic index of spaghetti cooked 5 or $15 \mathrm{~min}$ was reported by Wolever et al (29) in diabetics. When $\alpha$-amylase concentration is the limiting factor (activity $<600$ nkat), pasta of different size and/or after different cooking times can be differentiated in vitro for its susceptibility to hydrolysis by $\alpha$-amylase (18). This differentiation would be significant in vivo in subjects with low amylase secretion, such as infants, old people, or patients with deficiencies in intraluminal pancreatic enzymes.

Colonna et al (18) showed that preincubation of pasta with protease (pronase containing $<0.1 \%$ amylase activity) enhanced starch pasta amylolysis. Similar results were reported by Holm et al (10) with wheat starch, suggesting that a large fraction of the starch is encapsulated in a protein matrix. Scanning electron microscopy with use of freeze-fracturing and thin-sectioning confirmed that proteins coagulate to form a continuous network around each starch granule during pasta cooking (30), thereby providing a structural explanation for the low pasta plasma responses. The same reduced glycemic effect of starch-gluten interactions in bread was recently shown by Jenkins et al (11).

The technique of breath-hydrogen testing used here to study intestinal digestion of pasta starch, is based on the ability of colonic microflora to ferment carbohydrates unabsorbed at the end of the small intestine, with the resultant production of hydrogen. When analyzed, the raw-fiber content of pasta is

Previous studies (10-16) emphasized the role of food processing as a factor able to modify both in vitro food-starch $\alpha$ - 
TABLE I

Characteristics of plasma glucose response during 180 min after the start of test meals*

\begin{tabular}{|c|c|c|c|c|}
\hline & \multirow[b]{2}{*}{ OGTT } & \multicolumn{3}{|c|}{ Pasta meals } \\
\hline & & $T 1(11 \mathrm{~min})$ & $\mathrm{T} 2(16.5 \mathrm{~min})$ & $\mathrm{T} 3(22 \mathrm{~min})$ \\
\hline Fasting concentrations (mmol/L) & $4.6 \pm 0.1$ & $4.4 \pm 0.1^{\text {aa }}$ & $4.4 \pm 0.1^{\text {aa }}$ & $4.4 \pm 0.1^{\mathrm{aa}}$ \\
\hline$\triangle$ Peak above fasting value $(\mathrm{mmol} / \mathrm{L}) \dagger$ & $2.9 \pm 0.2$ & $1.2 \pm 0.1^{\mathrm{ea}}$ & $1.4 \pm 0.1^{\mathrm{ea}}$ & $1.3 \pm 0.2^{a}$ \\
\hline$د$ Peak under fasting value $(\mathrm{mmol} / \mathrm{L})$ & $-1.0 \pm 0.1$ & $-0.2 \pm 0.1^{\mathrm{ea}}$ & $-0.2 \pm 0.1^{\text {ea }}$ & $-0.3 \pm 0.1^{\mathrm{ea}}$ \\
\hline \multicolumn{5}{|l|}{$\begin{array}{l}\text { Peaking time (min) } \\
\text { Pand }\end{array}$} \\
\hline Peak above fasting value & $40 \pm 3$ & $31 \pm 2^{\mathrm{ba}}$ & $33 \pm 3^{\text {aa }}$ & $40 \pm 10^{\mathrm{aa}}$ \\
\hline Peak under fasting value & $130 \pm 14$ & $36 \pm 17^{\mathrm{da}}$ & $69 \pm 18^{\mathrm{da}}$ & $101 \pm 2^{\text {an }}$ \\
\hline \multicolumn{5}{|l|}{ Area under curve $\left(\mathrm{m} \mathrm{mol} \cdot \mathrm{L}^{-1} \cdot \min \right)$} \\
\hline $0-15 \mathrm{~min}$ & $6.1 \pm 0.6$ & $4.4 \pm 1.1^{\mathrm{aa}}$ & $4.4 \pm 1.1^{2 \mathrm{a}}$ & $3.9 \pm 1.1^{\text {aa }}$ \\
\hline $0-30 \mathrm{~min}$ & $29.4 \pm 2.8$ & $17.2 \pm 2.8^{\mathrm{ea}}$ & $17.8 \pm 2.2^{\mathrm{da}}$ & $15.0 \pm 2.8^{\mathrm{ea}}$ \\
\hline $0-60 \mathrm{~min}$ & $98.3 \pm 8.9$ & $40.0 \pm 6.1^{e a}$ & $44.9 \pm 5.0^{\text {ea }}$ & $37.7 \pm 7.8^{\mathrm{ea}}$ \\
\hline $0-90 \mathrm{~min}$ & $138.8 \pm 18.3$ & $51.6 \pm 8.3^{\mathrm{da}}$ & $55.5 \pm 7.8^{\mathrm{da}}$ & $47.7 \pm 11.1^{\mathrm{ea}}$ \\
\hline $0-180 \mathrm{~min}$ & $161.5 \pm 26.6$ & $71.6 \pm 13.3^{\mathrm{da}}$ & $77.7 \pm 12.2^{\mathrm{ca}}$ & $66.6 \pm 13.3^{\mathrm{da}}$ \\
\hline Glycemic index $(\%)$ & - & $59 \pm 15^{\mathrm{a}}$ & $65 \pm 15^{2}$ & $46 \pm 10^{a}$ \\
\hline
\end{tabular}

$* \bar{x} \pm$ SEM. OGTT, oral glucose-tolerance test. First (or only) letter gives significance between OGTT and pasta meals, second letter gives significance between pasta meals: a, NS; b, $p<0.05 ; c, p<0.02$; d. $p<0.01$; and $\mathrm{e}, p<0.00 \mathrm{l}$.

+ Difference between maximal and fasting values.

$\ddagger$ Difference between minimal and fasting values.

roughly 5-6 g/ $100 \mathrm{~g}$ dry matter and principally composed of hemicellulose (31). To assess the impact of this fiber component on breath excretion. Tadesse and Eastwood (32) fed $20 \mathrm{~g}$ hemicellulose to humans: hydrogen excretion was only onethird that observed with lactulose. Because Flourié et al (33) recently showed that the lactulose breath hydrogen test provides a valid measurement of the mean amount of starch metabolized in the colon of healthy subjects, it seems that starch malabsorption rather than dietary fiber represents the major portion of the hydrogen excreted after pasta ingestion. The 9-h postprandial test period was insufficiently long to allow breathhydrogen measurements to return to baseline concentrations for the quantification of starch malabsorption as described by Bond and Levitt (34); it was long enough to calculate the mouth-to-cecum transit time.

Although the fasting breath-hydrogen concentrations in our subjects were relatively high ( $15-20 \mathrm{ppm})$, they were in agree- ment with those reported elsewhere $(1,2,35)$. Overnight fermentation of colon-accumulated carbohydrates may account for the high initial fasting concentrations of hydrogen excretion $(35,36)$. Kotler et al $(37)$ demonstrated that an evening dinner leading to carbohydrate malabsorption before the breath test can reduce fasting concentrations of breath-hydrogen. In our study those carbohydrates consumed at the evening meal included starch from white rice $(50 \%)$ and white bread $(50 \%)$ and lactose ( $7 \mathrm{~g}$ ) from yogurt. Kolars et al (38) showed that lactose from yogurt is well absorbed, even in lactase-deficient subjects. Nevertheless, if a fraction of bread starch is incompletely absorbed $(2,11)$, such a quantity cannot account alone for the high fasting concentrations of hydrogen excretion $12 \mathrm{~h}$ after the start of a meal (11). Fermentation of mucins and glycoproteins have also been implicated in high fasting concentrations of breath hydrogen (39).

Immediately after pasta ingestion an initial increase in mean

TABLE 2

Characteristics of plasma insulin response during 180 min after the start of test meals*

\begin{tabular}{|c|c|c|c|c|}
\hline & \multirow[b]{2}{*}{ OGTT } & \multicolumn{3}{|c|}{ Pasta meals } \\
\hline & & $\mathrm{T} 1(11 \mathrm{~min})$ & $\mathrm{T} 2(16.5 \mathrm{~min})$ & $\mathrm{T} 3(22 \mathrm{~min})$ \\
\hline Fasting concentration (pmol/L) & $83.2 \pm 4.3$ & $74.6 \pm 3.6^{\mathrm{ag}}$ & $73.9 \pm 3.6^{\mathrm{aa}}$ & $81.8 \pm 3.6^{2 a}$ \\
\hline$\Delta$ Peak above fasting value $(\mathrm{pmol} / \mathrm{L}) \dagger$ & $482.9 \pm 51.7$ & $109.8 \pm 12.2^{\mathrm{da}}$ & $108.3 \pm 20.1^{\mathrm{da}}$ & $124.1 \pm 23.7^{\mathrm{da}}$ \\
\hline Peaking time: peak above fasting value ( $\mathrm{min}$ ) & $54 \pm 4$ & $36 \pm 4^{c a}$ & $35 \pm 5^{\mathrm{a}}$ & $53 \pm 12^{\mathrm{ca}}$ \\
\hline \multicolumn{5}{|l|}{ Area under curve $\left(\mathrm{nmol} \cdot \mathrm{L}^{-1} \cdot \mathrm{min}\right)$} \\
\hline $0-15 \mathrm{~min}$ & $0.9 \pm 0.1$ & $0.4 \pm 0.1^{\mathrm{ba}}$ & $0.6 \pm 0.1^{\text {as }}$ & $0.4 \pm 0.1^{b e}$ \\
\hline $0-30 \mathrm{~min}$ & $4.2 \pm 0.4$ & $1.6 \pm 0.3^{\mathrm{da}}$ & $1.8 \pm 0.3^{\mathrm{dz}}$ & $1.6 \pm 0.4^{\mathrm{da}}$ \\
\hline $0-60 \mathrm{~min}$ & $16.7 \pm 1.5$ & $3.9 \pm 0.6^{\mathrm{da}}$ & $4.2 \pm 0.9^{\mathrm{da}}$ & $4.3 \pm 1.1^{d a}$ \\
\hline $0-90 \mathrm{~min}$ & $27.8 \pm 3.4$ & $5.5 \pm 0.8^{d a}$ & $6.1 \pm 1.4^{\mathrm{da}}$ & $6.2 \pm 1.5^{\mathrm{da}}$ \\
\hline $0-180 \mathrm{~min}$ & $40.8 \pm 7.1$ & $8.5 \pm 1.5^{\mathrm{ca}}$ & $10.7 \pm 2.8^{\mathrm{da}}$ & $10.0 \pm 2.4^{\mathrm{da}}$ \\
\hline Glycemic index $(\%)$ & - & $26 \pm 5^{2}$ & $28 \pm 6^{a}$ & $26 \pm 6^{2}$ \\
\hline
\end{tabular}

$* \bar{x} \pm$ SEM. First (or only) letter gives significance between OGTT and pasta meals; second letter gives significance between pasta meals: a, NS; b. $p<0.05$; c. $p<0.02$; d, $p<0.01$; and e, $p<0.001$.

+ Difference between minimal and fasting values. 


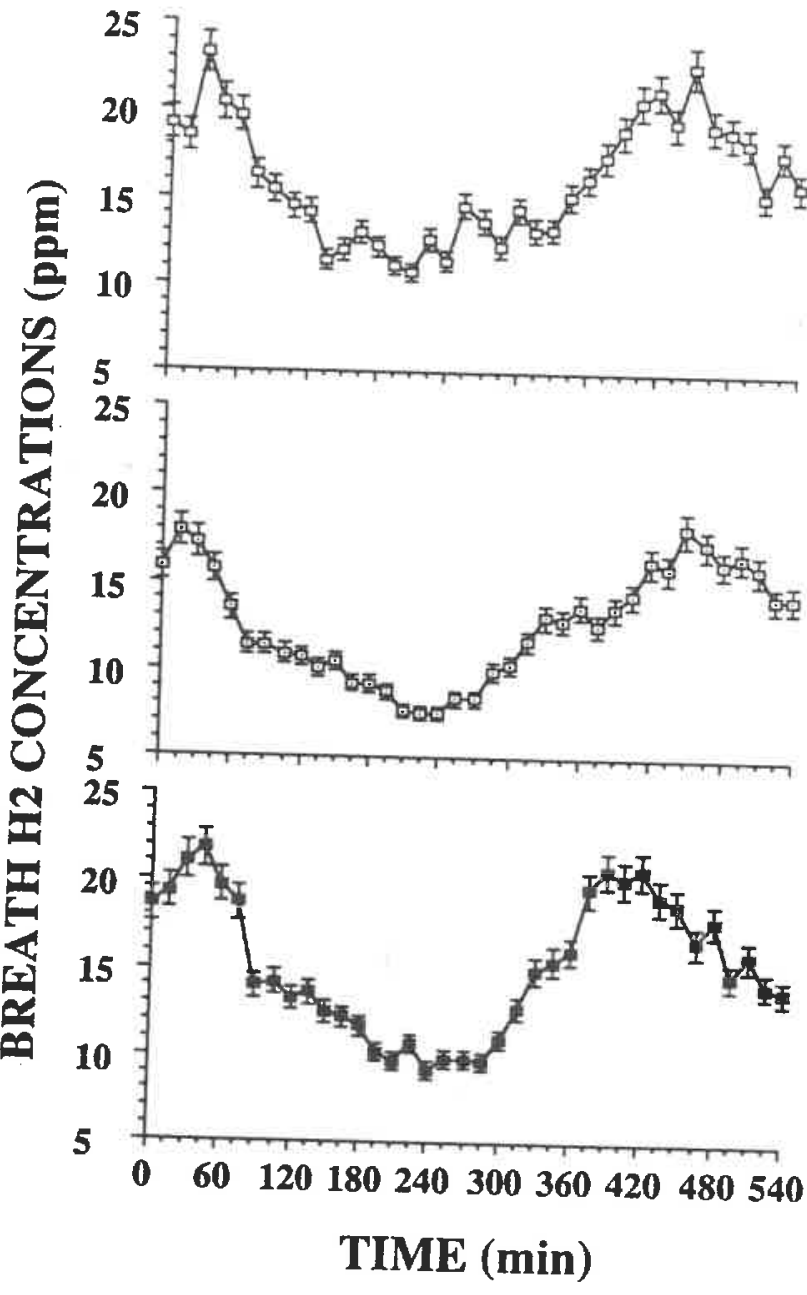

FIG 2. Breath-hydrogen excretion $(\vec{x} \pm$ SEM) in 12 healthy subjects after receiving pasta test meals cooked $11(\mathrm{~T} 1, \square), 16.5(\mathrm{~T} 2 . \square)$, and 22 $\min (T 3, \square)$. No significant differences were observed between the test meals at any time.

breath-hydrogen concentration was noted, followed by a gradual decrease to basal concentrations. Various hypotheses have been proposed to explain the early increase in breath hydrogen $(40,41)$. Because buccal carbohydrate fermentation contributes to some degree, oral hygiene has been proposed to eliminate this phenomenon (19). Despite the meticulous oral hygiene practiced in our trial, its effect seemed insufficient to to-

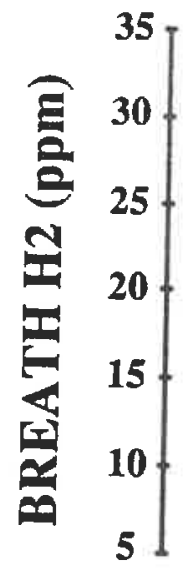

$\left.\begin{array}{r}35 \\ 30 \\ 25 \\ 20 \\ 15 \\ 10 \\ 5\end{array}\right]$

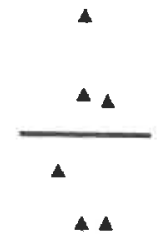

$\Delta$

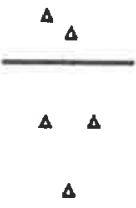

GROUP M(-)

GROUP M(+)

FIG 3. Maximal breath-hydrogen increments after pasta test meals for six nonmethane producers $(\mathrm{M}-$ ) and six methane producers $(\mathrm{M}+)$ Each triangle represents the mean value of the three test meals for a subject. Horizontal bars indicate mean value for each group. The difference between the mean group values was significant $(p<0.02)$.

tally eliminate the initial increase in hydrogen (42). It has also been hypothesized that soon after food ingestion, hydrogen production may be stimulated by the passage into the cecum of either ileal secretions or carbohydrates retained in the terminal ileum from a previous meal (40).

On the basis of the functional criterion defining starch malabsorption, 26 of 36 pasta meals were incompletely digested in the small bowel of the test subjects. Levitt et al (2) showed recently that $50 \mathrm{-g}$ starch doses in the form of various starchy foods (oats, potatoes, corn) gave rise to approximately one-half the hydrogen excretion observed with $100-\mathrm{g}$ doses. These data suggest that at least in healthy humans, the limiting factor for intestinal absorption of starch is the specific resistance of a given food to $\alpha$-amylolysis rather than to a deficit in enzyme availability. When comparing our data for pasta with their results, we estimate a starch pasta malabsorption of $<4 \%$, whatever the cooking time. This percentage is considerably less than the 10-20\% estimated by Anderson et al (1), who used $100 \mathrm{~g}$ starch in the form of macaroni boiled for $7 \mathrm{~min}$. It has been suggested that it is the protein moiety of durum-wheat flour that interferes with starch digestion $(1,10,11,18)$.

The criteria used to define a subject as a methane producer has varied. Initially, Bond et al (43) proposed that only those subjects with breath methane concentrations $>1 \mathrm{ppm}$ above

TABLE 3

Breath-hydrogen excretion after lactulose test and pasta test meals*

\begin{tabular}{|c|c|c|c|c|}
\hline & \multirow[b]{2}{*}{ Lactulose } & \multicolumn{3}{|c|}{ Pasta meals } \\
\hline & & $\mathrm{Tl}(11 \mathrm{~min})$ & $\mathrm{T} 2(16.5 \mathrm{~min})$ & T3 (22 min) \\
\hline $\begin{array}{l}\Delta \text { Breath-hydrogen concentration }(\mathrm{ppm}) \dagger \\
\text { Beginning of hydrogen excretion ( } \mathrm{min})\end{array}$ & $\begin{array}{l}45 \pm 4 \\
85 \pm 13\end{array}$ & $\begin{array}{c}20 \pm 1^{\text {an }} \\
274 \pm 27^{\text {ba }} \\
{[7]}\end{array}$ & $\begin{array}{c}19 \pm 1^{\text {aa }} \\
238 \pm 88^{\text {ba }} \\
{[9]}\end{array}$ & $\begin{array}{l}22 \pm 1^{\text {aa }} \\
278 \pm 49^{\text {ba }} \\
{[10]}\end{array}$ \\
\hline
\end{tabular}

* $\bar{x} \pm$ SEM. $n=12$ except where noted differently in brackets. First letter gives significance between lactulose and pasta meals; second letter gives significance between pasta meals: $\mathrm{a}, \mathrm{NS}$, and $\mathrm{b}, p<0.001$.

$\dagger$ Difference between the maximal increment of hydrogen concentration and the nadir of hydrogen concentration. 
atmospheric methane be arbitrarily designated as methane producers. However, a single breath sampling may fail to detect an average of $18 \%$ of the methane producers in a given population (44). More recently, McKay et al (45) demonstrated that all healthy subjects may produce methane. though production of the gas appears in breath only after reaching a certain threshold. These investigators defined a methane producer as a subject emitting $\geq 2$ ppm above room air concentration, on the basis of the sensitivity and reproducibility of the method used. In our study the smallest detectable methane concentration was 2 ppm; thus. our methane producers were defined as subjects producing mean methane concentrations of $\geq 3 \mathrm{ppm}$ above those in ambient air after two breath samples.

Our results demonstrated a significant difference in breathhydrogen concentration between healthy methane and nonmethane producers after pasta test meals, with a lower mean breath-hydrogen concentration peak in the methane producers. With one exception, those subjects who did not show evidence for starch malabsorption were all methane producers as well.

Hydrogen and methane in human breath derive entirely from bacterial fermentation in the intestinal lumen; neither hydrogen nor methane are used by cells of human organisms. In vivo methane production does not seem to be influenced by acute ingestion of carbohydrates such as starch (41), beans, or onions (46). However, dietary pectin (47) or xylane (48) can increase baseline concentrations of breath methane. Only large lactulose loads ( $\geq 20 \mathrm{~g}$ ) can increase methane production (49). Methane production has been correlated with basal methane concentrations. Björneklett et al (50) found that, in healthy subjects. methane producers who excreted $>10$ ppm methane had significantly lower fasting breath hydrogen and breath-hydrogen excretion after ingestion of $33 \mathrm{~g}$ lactulose than did methane producers who excreted $<10 \mathrm{ppm}$. These results and our own suggest that hydrogen production might be related to methane-producer status. Therefore. we may well have underestimated the number of pasta meals that have been incompletely absorbed by methane producers. In such a subpopulation the criteria heretofore used to assess starch malabsorption when using the breath-hydrogen method may not be adequate. If revised criteria are not established to gauge malabsorption of starchy foods in methane producers, it may be necessary to either increase the amount of starch tested, which must then be considered as an extraphysiologic meal, or to select only nonmethane producers as subjects.

We thank D Klein (BSN group), M Walle (PANZANI), and S Mouzay (Syndicat des Industriels Fabricant de Pâtes Alimentaires de France) for the selection and handling of the pasta. We are grateful to JP Rémi, Department of Nuclear Medicine, Hôtel Dieu Hospital, Nantes. as well as M Rival and F Doulay, INRA-Nantes, for their technical help.

\section{References}

1. Anderson IH, Levine AS, Levitt MD. Incomplete absorption of the carbohydrate in all-purpose wheat flour. N Engl J Med 1981;304: $891-2$.

2. Levitt MD. Hirsh $P$, Fetzer A, Sheahan M, Levine AS. $\mathbf{H}_{2}$ excretion after ingestion of complex carbohydrates. Gastroenterology 1987:92:383-9.

3. Jenkins DJA. Wolever TMS, Taylor RH, et al. Glycemic index of foods: a physiological basis for carbohydrates exchange. Am J Clin Nutr 1981;34:362-6.

4. Jenkins DIA. Wolever TMS. Jenkins AL, Lee R, Wong GS. Josse R. Glycemic response to wheat products: reduced response to pasta but no effect of fiber. Diabetes Care 1983;6:155-9.

5. Bornet FRJ, Costagliola D. Riskalla S. et al. Insulinemic and glycemic indexes of six starch-rich foods taken alone and in a mixed meal by type 2 diabetics. Am J Clin Nutr 1987;45:588-95.

6. Goddard MS, Young G. Marcus R. The effect of amylose content on insulin and glucose responses to ingested rice. Am J Clin Nutr 1984:42:495-503.

7. Bornet FRJ. Fontvielle A-M, Rizkalla S, et al. Insulin and glycemic responses in healthy humans to native starches processed in different ways: correlation with in vitro $\alpha$-amylase hydrolysis. Am J Clin Nutr 1989;50:315-23.

8. Potter JG. Coffman KD, Reid RL, Krall JM, Albrink MJ. Effect of test meals of varying dietary fiber content on plasma insulin and glucose response. Am J Clin Nutr 1981; 34:328-34.

9. Haber GB, Heaton KW, Murphy D, Burroughs LF. Depletion and disruption of dietary fiber: effects on satiety, plasma glucose and insulin. Lancet 1977:2:679-82.

10. Holm J. Björck I. Asp N-G, Sjöberg L-B. Lundquist I. Starch availability in vitro and in vivo after flaking. steam-cooking and popping of wheat. J Cereal Sci 1985:3:193-206.

11. Jenkins DJA, Thorne MJ, Wolever TMS, Jenkins AL, Rao AV, Thompson LU. The effect of starch-protein interaction in wheat on the glycemic response and rate of in vitro digestion. Am J Clin Nutr 1987:45:946-51.

12. Björck I, Asp N-G, Birkhed D, Lundquist l. Effects of processing on availability of starch for digestion in vitro and in vivo: extrusion cooking of wheat flour and starch. J Cereal Sci 1984:2:91-103.

13. Holm J, Björck I, Asp N-G, Sjöberg LB, Lundquist I. Starch availability in vitro and in vivo: extrusion cooking and popping of wheat. J Cereal Sci 1985; 3:193-206.

14. Brand JC, Nicholson PL, Thoburn AW, Truswell AS. Food processing and glycemic index. Am J Clin Nutr 1985;42:1 192-6.

15. Vaaler $S$, Hanssen KF, Aagenzes $O$. The effect of cooking upon the blood glucose response to ingested carrots and potatoes. Diabetes Care 1984:7:221-3.

16. Golay A, Coulston AM, Hollenbeck CB, Kaiser LL, Würsch P, Reaven G. Comparison of metabolic effects of white beans processed into two different physical forms. Diabetes Care 1986;9: 260-6.

17. Association Française de Normalisation (AFNOR). Semolinas of durum wheat and pasta products. Estimation of the cooking quality of spaghetti by sensory analysis (Reference method). Paris: AFNOR 1981:1-8. (Publication NF V 03-71.)

18. Colonna P, Barry J-L, Cloarec D, Bornét FRJ, Gouilloud S, Galmiche J-P. Enzymic susceptibility of starch from pasta. J Cereal Sci (in press)

19. Thompson DG, O'Brien JD, Hardie JM. Influence of the oropharyngeal microflora on the measurement of exhaled breath hydrogen. Gastroenterology 1986;91:853-60.

20. Mastropaolo G, Rees WDW. Evaluation of the hydrogen breath test in man: definition and elimination of the early hydrogen peak. Gut 1987;28:721-5.

21. Metz G, Jenkins DJA, Peters TJ, Newman A, Blendis LM. Breath hydrogen as a diagnostic method for hypolactasia. Lancet 1975; 1: $1155-7$.

22. Solomons NW. Evaluation of carbohydrate absorption: the hydrogen breath test in clinical practice. Clin Nutr J 1984;3:71-8.

23. Rumessen JJ, Gudmand-Hoyer E. Retention and variability of hydrogen $\left(\mathrm{H}_{2}\right)$ samples stored in plastic syringes. Scand J Clin Lab Invest 1987;47:627-30.

24. Barr RG. Limitations of hydrogen breath test and other techniques for predicting incomplete lactose absorption. In: Paige DM, Bay- 
less TM, eds. Lactose digestion: clinical and nutritional implications. Baltimore: Johns Hopkins University Press. 1981:110-4.

25. Bond $\mathrm{JH}$, Levitt $\mathrm{MD}$. Investigation of small bowel transit time in man utilizing pulmonary hydrogen $\left(\mathrm{H}_{2}\right)$ measurements. J Lab Clin Med 1975;85:546-55.

26. La Brooy SJ, Male PJ, Beavis AK, Misiewicz JJ. Assessment of reproducibility of the lactulose $\mathrm{H}_{2}$ breath test as a measure of mouth to caecum transit time. Gut 1983:24:893-6.

27. Winer BJ. Statistical principles in experimental design. New York: McGraw Hill, 1971.

28. Guilbot A, MercierC. Starch. In: Aspinall GO. ed. The polysaccharides. London: Academic Press, 1985:209-82.

29. Wolever TMS, Jenkins DJA, Kalmusky J, et al. Glycemic response to pasta: effect of surface area. degree of cooking. and protein enrichment. Diabetes Care 1986;9:401-4.

30. Pagani MA. Gallant DJ, Bouchet B. Resmini P. Ultrastructure of cooked spaghetti. Fond Microstructure 1986:5:1 I1-29.

31. Wenlock RW, Sivell LM, Agater IB. Dietary fibre fractions in cereal and cereal-containing products in Britain. J Sci Food Agric 1985:36:113-21.

32. Tadesse K, Eastwood A. Metabolism of dietary fibre components in man assessed by breath hydrogen and methane. Br J Nutr 1978:40:393-6.

33. Flourié B, Florent C, Etanchaud F, Evard D. Franchisseur C. Rambaud J-C. Starch absorption by healthy man evaluated by lactulose hydrogen breath test. Am J Clin Nutr 1988:47:61-6.

34. Bond $\mathrm{JH}$, Levitt MD. Use of pulmonary hydrogen $\left(\mathrm{H}_{2}\right)$ measurements to quantitate carbohydrate absorption. Study of partially gastrectomized patients. J Clin Invest 1972;51:1219-25.

35. Perman JA, Modler S, Barr RG. Rosenthal P. Fasting breath hydrogen concentration: normal values and clinical application. Gastroenterology 1984;87:1358-63.

36. Brummer RJM, Armbrecht U, Bosaeus I. Dotevall G. Stockbruegger RW. The hydrogen $\left(\mathrm{H}_{2}\right)$ breath test. Scand J Gastroenterol 1985;20:1007-13.

37. Kotler DP. Holt PR, Rosenweig NS. Modification of the breath hydrogen test: increased sensitivity for the detection of carbohydrate malabsorption. J Lab Clin Med 1982: 100:798-805.
38. Kolars JC, Levitt MD. Aouji M, Savaiano DA. Yogurt-an autodigesting source of lactose. N Engl J Med 1984; 310:1-3.

39. Perman JA. Modler S. Glycoproteins as substrates for production of hydrogen and methane by colonic bacterial flora. Gastroenterology 1982:83:388-93.

40. Read NW, Al-Janabi MN, Bates TE, et al. Interpretation of breath hydrogen profile obtained after ingesting a solid meal containing unabsorbable carbohydrate. Gut 1985:26:834-42.

41. Rumessen JJ, Kokholm G, Gudmand-Hoyer E. Methodologica aspects of breath hydrogen $\left(\mathrm{H}_{2}\right)$ analysis. Evaluation of a $\mathrm{H}_{2}$ monitor and interpretation of the breath $\mathrm{H}_{2}$ test. Scand $\mathrm{J}$ Lab Invest 1987:47:555-60.

42. Thompson DG, Binfield P, De Belder A, O'Brien J, Warren S, Wilson $M$. Extra-intestinal influences on exhaled breath hydrogen measurement during the investigation of gastrointestinal disease. Gut 1985;26:1349-52.

43. Bond JH. Engel RR, Levitt MD. Factors influencing pulmonary methane excretion in man. J Exp Med 1971;133:572-88.

44. Pitt P, De Bruijn KM. Beeching M, Goldberg E, Blendis LM. Studies on breath methane: the effect of ethnic origins and lactulose. Gut 1980;21:951-9.

45. McKay LF, Eastwood MA, Brydon WG. Methane excretion in man-a study of breath. flatus, and faeces. Gut 1985:26:69-74.

46. Calloway DH. Respiratory hydrogen and methane as affected by consumption of gas-forming foods. Gastroenterology 1966:51: $383-9$.

47. Marthinsen D, Flemming SE. Excretion of breath and flatus gases by humans consuming high-fiber diets. J Nutr 1982: 1 12:1 133-43.

48. Flatz G. Czeizel A. Metneki J, Flatz SD, Kulnau W, Jahn D. Pulmonary hydrogen and methane excretion following ingestion of an unabsorbable carbohydrate: a study of twins. J Pediatr Gastroenterol Nutr 1985:4:936-41.

49. Beaven J, Björneklett A, Jenssen E, Blomhoff JP. Skrede S. Pulmonary hydrogen and methane and plasma ammonia after administration of lactulose or sorbitol. Scand J Gastroenterol 1983:18: 343-7.

50. Björneklett A, Jenssen E. Relationships between hydrogen $\left(\mathrm{H}_{2}\right)$ and methane $\left(\mathrm{CH}_{4}\right)$ production in man. Scand $\mathrm{J}$ Gastroenterol $1982: 17: 985-92$ 